\title{
Comparison between biodegradable polymers from cassava starch and glycerol as additives to biogas production
}

\section{Comparação entre glicerol e polímero biodegradável a base de mandioca como aditivos na biodigestão anaeróbia}

\author{
Paulo André Cremonez ${ }^{1 *}$; Armin Feiden²; Joel Gustavo Teleken³; \\ Samuel Nelson Melegari de Souza²; Michael Feroldi'; \\ Thompson Weiser Meier ${ }^{5}$; Jhony Tiago Teleken ${ }^{6}$; Jonathan Dieter ${ }^{3}$
}

\begin{abstract}
In this study, we compared cassava starch-based biodegradable polymers (PBMs) and glycerol (G) as additives used to increase biogas production from the co-digestion of swine wastewater (ARS). We chose to work with an inoculum comprising $40 \%(\mathrm{v} / \mathrm{v})$ of the total volume of the reactor; this inoculum was obtained from a Canadian model digester for treating swine waste. In the anaerobic digestion process, batch reactors were used on a laboratory scale with a total volume of approximately $4 \mathrm{~L}$ and a working volume of $3.2 \mathrm{~L}$. Three treatments were conducted to compare the efficiency of solid removal, the chemical oxygen demand (COD), and the production of biogas. The first treatment contained only swine waste; the second included the addition of glycerol at 1,3 , and $5 \%(\mathrm{w} / \mathrm{v})$; and the third treatment included the addition of 1,3 , and $5 \%(\mathrm{w} / \mathrm{v})$ of PBM residue in relation to the swine wastewater. From the results, it can be concluded that higher yields were obtained for the treatment with 3\% PBM and 1\% glycerol. Most treatments showed high removal rates of total solids and total volatile solids. Reductions lower than $70 \%$ were obtained only for treatments with PBM and glycerol at a ratio of $5 \%$.
\end{abstract}

Key words: Additives. Alternative fuels. Biodegradable polymers. Glycerol.

\section{Resumo}

O presente trabalho tem por finalidade comparar o potencial aditivo no aumento da produção de biogás de polímeros biodegradáveis a base de fécula de mandioca (PBM) e do glicerol, já comumente empregado com essa finalidade, ambos em co-digestão com água residuária de suinocultura. Utilizouse como matéria-prima para produção de biogás, água residual de suinocultura, material plástico biodegradável produzido a partir de fécula de mandioca e glicerina bruta proveniente do processo de produção de biodiesel. Optou-se por trabalhar com $40 \%$ (v/v) de inóculo do volume total do reator. Para a condução do processo de digestão anaeróbia empregaram-se reatores com alimentação batelada

\footnotetext{
${ }^{1}$ Mestre em Engenharia de Energia na Agricultura, Discente de Doutorado do Programa de Pós-Graduação em Engenharia Agrícola, Universidade Estadual do Oeste do Paraná, UNIOESTE, Cascavel, PR, Brasil. E-mail: pa.cremonez@gmail.com

2 Profs. Permanente, Programa de Pós-Graduação em Engenharia de Energia na Agricultura, UNIOESTE, Cascavel, PR, Brasil. E-mail: armin.feiden@gmail.com; samuel.souza@unioeste.br

${ }^{3}$ Profs. Permanente, Programa de Pós-Graduação em Bioenergia, Universidade Federal do Paraná, UFPR, Palotina, PR, Brasil. E-mail: Joel.teleken@ufpr.br;

${ }^{4}$ Discente do programa de Pós-Graduação em Engenharia de Energia na Agricultura, UNIOESTE, Cascavel, PR, Brasil. E-mail: michaelferoldi@gmail.com

${ }^{5}$ Discente, Programa de Pós-Graduação em Bioenergia, UFPR, Palotina, PR, Brasil. E-mail: thomweiser@yahoo.com.br

${ }^{6}$ Discente, Programa de Pós-Graduação em Engenharia de Alimentos, Universidade Federal de Santa Catarina, UFSC, Florianópolis, SC, Brasil. E-mail: jhony tt@yahoo.com.br

* Author for correspondence
} 
de escala laboratorial de volume total de aproximadamente 4 litros e volume útil de 3,2 litros. Foram realizados 3 tratamentos visando comparar a eficiência da remoção de sólidos, demanda química de oxigênio e produção de biogás. O primeiro tratamento conteve apenas resíduo de suíno, o segundo a adição de glicerol em percentuais de 1,3 e $5 \%(\mathrm{~m} / \mathrm{v})$ no mesmo resíduo e o terceiro a adição de 1 , 3 e $5 \%(\mathrm{~m} / \mathrm{v})$ do polímero biodegradável a base de fécula de mandioca ao resíduo suíno. A partir dos resultados pode-se concluir que as maiores produções foram obtidas no tratamento de $3 \%$ de PBM e $1 \%$ de glicerol. A maioria dos tratamentos apresentou elevadas taxas de remoção de sólidos totais e sólidos totais voláteis. Apenas os tratamentos com PBM e glicerol na proporção de 5\% obtiveram reduções inferiores a $70 \%$.

Palavras-chave: Aditivos. Glicerol. Polímeros biodegradáveis. Combustíveis alternativos.

\section{Introduction}

Biomass is an important global alternative source of energy to fossil fuels. This is a result of the excessive demand, high cost, and dwindling reserves of fossil fuels, together with issues relating to environmental degradation and the worsening greenhouse effect (BRIDGWATER et al., 1999).

The energy derived from biomass offers great possibilities for research and application. Traditional sources, such as firewood and vegetation-derived coal, are giving way to modern biomass alternatives (bioalcohol, biokerosene, biodiesel, and biogas), which offer more efficient forms of energy production (MIURA et al., 2011).

Taking into account its high potential for reducing greenhouse gases and because of its decentralization, the use of residual agricultural biomass for the production of biogas can contribute significantly to sustainable development in rural areas, as well as securing a new source of income for farmers (CAVINATO et al., 2010).

Considered an important source of renewable energy, biodiesel is intended to complement both the Brazilian and global energy matrix (OSAKI; BATALHA, 2011). During biofuel production, vegetable oils or animal fats react with an alcohol (methanol, ethanol, or a higher alcohol) to produce fatty acid esters and glycerol (G) as byproducts (CARMO et al., 2014). Refined glycerin has several industrial applications, but is mainly used in the production of cosmetics and medicines. However, the glycerin obtained from biodiesel production contains many impurities, such as water and the residues of fatty acids and catalysts, and a high chemical oxygen demand (COD) is associated with the process (FREITAS; PENTEADO, 2006; SANTIBAÑEZ et al., 2011). Because refining this glycerin is mostly unfeasible, it has limited usefulness.

The search for less environmentally damaging materials has encouraged many studies aimed at obtaining biodegradable films intended to replace synthetic plastics (BHATNAGAR; SAIN, 2005; CORRADINI et al., 2008; ZHANG et al., 2007). Starch films have been investigated intensively, mainly owing to the availability and low cost of starch, which usually is obtained from commercial plantations growing cassava, wheat, or corn (ALVES et al., 2012).

Like glycerol, biodegradable plastics mainly consist of hydrogen and carbon; they are capable of undergoing rapid degradation by means of anaerobic biodigestion processes, and can be co-digested with other industrial residues, with the aim of increasing biogas production. Therefore, in the present work, our objective was to investigate the use of cassava starch-based biodegradable polymers and glycerol for co-digestion with swine wastewater to increase biogas production.

\section{Materials and Methods}

\section{Substrates for digestion}

Swine wastewater (ARS), cassava starch-based biodegradable polymers (PBMs), and raw glycerol (G), a byproduct of biodiesel production, were used as raw materials for the production of biogas. 
The ARS was obtained from a swine breeding estate located in Palotina City, Parana State, Brazil. The residue was obtained after the grading phase of the raw residue; it was collected in polyethylene bottles and refrigerated until required.

The biodegradable plastic material was obtained from disposable coffee cups. It was acquired from a company that specializes in the production of starch-based biodegradable polymeric materials. The cups were ground in a processor to an average fragment size of less than $2.0 \mathrm{~cm}$.

As already mentioned, the raw glycerol was obtained from the Biofuel Production Laboratory at the Federal University of Parana, Palotina Sector, Parana State, Brazil. The residual methanol was separated from the raw material by distillation, and the sodium hydroxide residues were removed by successive washing of the material with water.

\section{Inoculum}

The inoculum used for starting the experiment was obtained from an estate located in Palotina City, Parana State, Brazil, from a Canadian model biodigester, operated with liquid waste from swine breeding. We chose to operate the biodigester with $40 \%(\mathrm{v} / \mathrm{v})$ inoculum based on the total volume of the biodigester, in accordance with studies performed by Xavier and Lucas Júnior (2010).

\section{Laboratory-scale biodigesters and gasometers}

The process of anaerobic digestion was conducted in a boatload system using reactors built from polyvinyl chloride (PVC) with dimensions of $100 \mathrm{~mm}$ diameter and $500 \mathrm{~mm}$ height, making a total volume of approximately $4 \mathrm{~L}$.
This fermentation chamber kept the organic material mixture in anaerobiosis, where methanogenic bacteria were involved in biogas production. A working volume of $3.20 \mathrm{~L}$ was established in the reactor, leaving $20 \%$ of the total volume free. The biodigester was fed only at the beginning of the process.

Two treatments were carried out to compare solid removal efficiency, COD, and biogas production with a control treatment. The control treatment comprised only solid swine waste, while the other treatments were performed by testing the addition of glycerol at 1,3 , and $5 \%(\mathrm{w} / \mathrm{v})$ in the same residue, as well as treatments with the addition of 1,3 , and $5 \%$ (w/v) cassava starch-based biodegradable polymer to the swine residue.

The gasometers and reactors were built from PVC and had the following dimensions: 100 $\mathrm{mm}$ diameter and $300 \mathrm{~mm}$ length. These were connected to $150-\mathrm{mm}$ tubes sealed with acidified saline solution, whereas the gasometers and their rulers were partially submersed in a tank containing the same solution. This solution comprised $25 \%$ (v/v) sodium chloride and 3\% (v/v) sulfuric acid; it prevented the escape of biogas and blocked the dissolution of $\mathrm{CO}_{2}$ in the water (LARSEN, 2009).

PVC connectors and silicone hoses were used to couple the reactors to their respective gasometers, and the withdrawal of gas was carried out by means of a $\mathrm{T}$ connector coupled to the hose. The representative arrangement of the experimental apparatus is shown in Figure 1. 
Figure 1. Construction arrangement of the reactors and gasometers: a) $100-\mathrm{mm}$ PVC reactors; b) thermostat to control the temperature; c) homemade incubator; d) 1" silicone hose; e) outlet for withdrawal of gas; f) $100 \mathrm{~mm}$ PVC gasometer; g) water sealant (saline solution); h) gasometer ruler; i) heater.

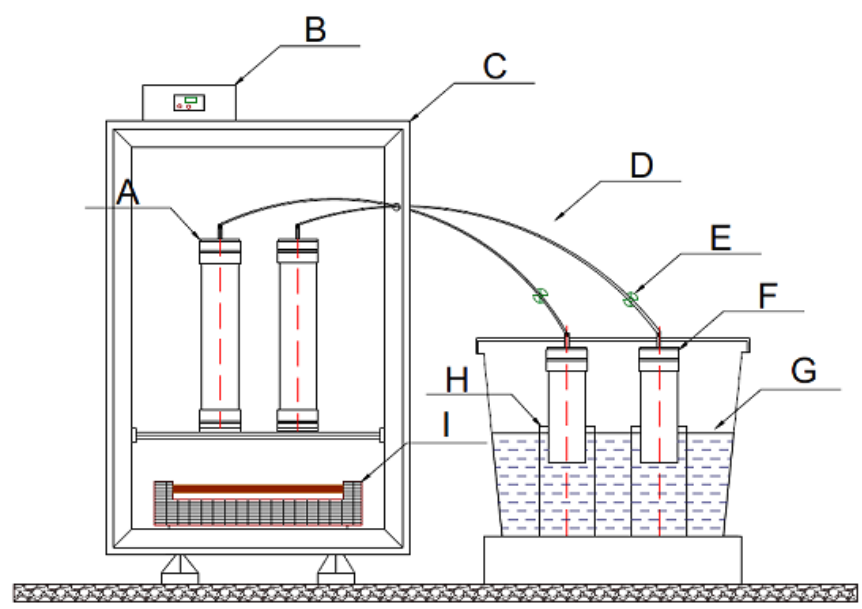

The volume of generated gas was measured from the vertical displacement of the gasometers with a correction for standard temperature and pressure, according to Equation 1, as used by Aquino et al. (2007).

$$
\frac{\mathrm{P}_{1} \mathrm{~V}_{1}}{\mathrm{~T}_{1} \text { (STP) }}=\frac{\mathrm{P}_{2} \mathrm{~V}_{2}}{\mathrm{~T}_{2}}
$$

Where:

$\mathrm{P}_{1}=$ standard pressure $(\mathrm{mmHg})$

$\mathrm{V}_{1}=$ volume $(\mathrm{L})$

$\mathrm{T}_{1}=$ standard temperature $(\mathrm{K})$

$\mathrm{P}_{2}=$ local pressure, Palotina, Parana State $(\mathrm{mmHg})$

$\mathrm{V}_{2}=$ sampling volume $(\mathrm{L})$

$\mathrm{T}_{2}=$ measured temperature at the moment of sampling $(\mathrm{K})$
For controlling the temperature, a set-point of $35^{\circ} \mathrm{C}( \pm 1)$ was established, with an independent digital thermometer to monitor the internal temperature of the incubators. The whole system for the capture of digested effluent and the withdrawal of biogas was built externally to the incubators.

\section{Parameters for treatment of the residue}

The samples of solid residue and inoculum were submitted to tests for $\mathrm{pH}$, volatile acidity (VA), total alkalinity (TA), intermediate alkalinity (IA), and partial alkalinity (PA), to determine the condition of the material to be digested, thereby ensuring efficiently. The methods employed in the analysis and their respective references are described in Table 1. 
Table 1. Methods employed in the determination of parameters.

\begin{tabular}{cc}
\hline Parameter & Method \\
\hline $\mathrm{pH}$ & Potentiometric (4500-H*/APHA, 1995) \\
COD & Colorimetric (5220-D/APHA, 1995) \\
TS & Gravimetric (2540-B/APHA, 1995) \\
VTS & Gravimetric (2540-E/APHA, 1995) \\
FTS & Gravimetric (2540-E/APHA, 1995) \\
VA & Volumetric (Silva, 1977) \\
TA & Volumetric (Silva, 1977) \\
PA & Volumetric (Silva, 1977) \\
IA & Volumetric (Silva, 1977) \\
\hline
\end{tabular}

\section{Other input parameters}

For the materials to be digested, we determined the COD, total solids (TS), volatile solids (VS), and fixed solids (FS). All the analyses performed on the reactor input material were also carried out on samples collected from the output, allowing a comparison of efficiency in all repetitions of the treatment. The methods used in the analyses, together with their respective references, are included in Table 1.

We established a hydraulic retention time (HRT) of 6 days for the evaluation of this work; we aimed to evaluate the increase in the production of biogas in this period. According to the literature, the high solubility and superior degradation capacity of the glycerol and the residue from the grinding of the disposable cups were compared with those of their inorganic counterparts (ALVES et al., 2012).

\section{Characterization of the gas}

For the present study, the biogas was collected from the reactors through a sampling vessel. We washed the biogas using an alkaline solution from a specific kit for biogas that consisted of a glass syringe equipped with a bracket connecting another syringe containing alkaline solution. The AlfaKit ${ }^{\mathbb{R}}$, with the methodology employed by the official network of the EMBRAPA soil laboratories, presents an accuracy of $2.5 \%$ and aims to assist owners of rural biodigesters in controlling parameters such as methane content percentage, carbon dioxide, ammonia, and sulfidric acid present in the gas (ALFAKIT, 2016).

\section{Kinetics of biogas production}

The data on the accumulated production of biogas in all the treatments were modeled based on the Gompertz equation (LAY et al., 1996). Such empirical equations are commonly employed, and aim to interpret the basic subjacent mechanisms of biogas production in biodigestion processes (LAY et al., 1997; PARAMESWARAN; RITTMANN, 2012; YUSUF et al., 2011). The Gompertz model describes the accumulated production of gas, assuming the gas production as a function of bacterial growth, as described by Equation 2:

$$
M(t)=P \exp \left\{-\exp \left[\frac{R}{P} e(\lambda-t)+1\right]\right\}
$$

Where:

$\mathrm{M}=$ observed accumulated biogas production $(\mathrm{mL})$

$\mathrm{P}=$ final biogas production $(\mathrm{mL})$

$\mathrm{R}=$ obtained biogas production rate $\left(\mathrm{mL} \mathrm{h}^{-1}\right)$

$\lambda=$ time lag $(\mathrm{h})$

$\mathrm{t}=$ observation time $(\mathrm{h})$

$\mathrm{e}=$ the exponential constant (2.717) 
We fitted the Gompertz equation to the experimental data by using the "fit" function of the "curve fitting tool" available with MatLab R2011b software, release 7.13 (MathWorks, Natick, MA, USA). The performance of the model was assessed using the determination coefficient $\mathrm{R}^{2}$.

\section{Statistical analysis}

A completely randomized experimental design was used in which the two treatments with their three levels, together with the control treatment (Table 2), had five repetitions. We used analysis of variance (ANOVA) and the Tukey test at 5\% probability to check statistical differences between the treatments.

Table 2. Mix levels of wastes and additives in the studied treatments.

\begin{tabular}{lcccc}
\hline \multirow{2}{*}{ Treatment (working volume = 3.2 L) } & \multicolumn{4}{c}{ Composition $\left(\%^{*}\right)$} \\
\cline { 2 - 5 } & Inoculum & ARS & PBM & Glycerol \\
\hline Control & 40 & 60 & - & - \\
G1 & 40 & 59 & - & 1 \\
G3 & 40 & 57 & - & 3 \\
G5 & 40 & 55 & - & 5 \\
PBM1 & 40 & 59 & 1 & - \\
PBM3 & 40 & 57 & 3 & - \\
PBM5 & 40 & 55 & 5 & - \\
\hline
\end{tabular}

*Additives $(\mathrm{w} / \mathrm{v})$

\section{Results and Discussion}

\section{Operational characteristics}

We checked separately the VA/TA ratios for the inoculum and ARS used in the biodigestion process. The ratios obtained were 0.067 for ARS and 0.4500 for the inoculum, both values favoring the biodigestion process. A ratio of 0.5 is considered good, the ideal range being 0.1-0.3 (VAN HAANDEL, 1994; FERNANDES JÚNIOR, 1995). Ripley et al. (1986) claim that a ratio above 0.3 indicates disturbances in the biodigestion process, whereas Chernicharo (1997) maintains that, owing to the particularities of each effluent, processes with higher ratios can often occur. Because of the characteristics of glycerol and the biodegradable polymer, VA/TA analysis was not performed.
These relationships are extremely important for the maintenance of $\mathrm{pH}$. Acidogenic bacteria prefer a slightly acidic $\mathrm{pH}$ and methane-producing bacteria thrive at neutral $\mathrm{pH}$. The volatile acids produced in the previous phases of methanogenesis produce carbonates and bicarbonates, which inhibit methane-producing bacteria (YE et al., 2013).

According to this relationship, the $\mathrm{pH}$ is an important factor that defines the efficiency of the biodigestion process, and it must be controlled. The optimum $\mathrm{pH}$ range for biodigestion is 6.87.2 (CHERNICHARO, 1997; YADVIKA et al., 2004), although the process continues efficiently at $\mathrm{pH}$ values of 6-8. In that light, the observed $\mathrm{pH}$ values in the different treatments were acceptable for starting up the biodigestion process. From Table 3 , we can visualize the characteristics of the reactor input materials for the seven treatments. 
Table 3. Input parameters of the studied treatments.

\begin{tabular}{|c|c|c|c|c|}
\hline \multirow{2}{*}{ Treatments } & \multicolumn{4}{|c|}{ Parameter $\left(\mathrm{mg} \mathrm{L}^{-1}\right)$} \\
\hline & COD & TS & VS & FS \\
\hline ARS (Control) & 22226.03 & 31240.00 & 22280.00 & 8960.00 \\
\hline G1 & 45053.14 & 35185.40 & 25695.10 & 9490.30 \\
\hline G3 & 92458.89 & 44821.80 & 34272.90 & 10549.00 \\
\hline G5 & 124211.52 & 54458.30 & 42573.50 & 11884.80 \\
\hline PBM1 & 60543.64 & 35467.20 & 26654.10 & 8813.10 \\
\hline PBM3 & 121746.71 & 45667.20 & 36734.10 & 8933.10 \\
\hline PBM5 & 179549.53 & 55867.20 & 46814.10 & 9053.10 \\
\hline ARS & & & Inoculum & \\
\hline $\mathrm{pH}$ & 7.22 & & $\mathrm{pH}$ & 8.08 \\
\hline $\mathrm{TA}\left(\mathrm{mg} \mathrm{L}^{-1}\right)$ & 4024.6 & & $\mathrm{TA}\left(\mathrm{mg} \mathrm{L}^{-1}\right)$ & 3200.2 \\
\hline $\mathrm{PA}\left(\mathrm{mg} \mathrm{L}^{-1}\right)$ & 2825.1 & & $\mathrm{PA}\left(\mathrm{mg} \mathrm{L}^{-1}\right)$ & 750.3 \\
\hline $\mathrm{IA}\left(\mathrm{mg} \mathrm{L}^{-1}\right)$ & 1175.2 & & $\mathrm{IA}\left(\mathrm{mg} \mathrm{L}^{-1}\right)$ & 2450 \\
\hline $\mathrm{VA}\left(\mathrm{mg} \mathrm{L}^{-1}\right)$ & 270.43 & & $\mathrm{VA}\left(\mathrm{mg} \mathrm{L}^{-1}\right)$ & 1440.1 \\
\hline
\end{tabular}

The concentrations of total solids present in the treatments were $3.12 \%$ (control/ARS); 3.51\% (G1); 4.48\% (G3); 5.45\% (G5); 3.55\% (PBM1); 4.57\% (PBM3), and 5.58\% (PBM5). Piston flow digesters and covered ponds should not show high solids contents, and complete mixing reactors are suitable for solid content between 2 and 10\% (OREGON STATE DEPARTMENT OF ENERGY, 2002), a range in which the movement of material inside the biodigester is also facilitated, besides preventing clogging in the input and output tubes of the reactor.

Table 4 illustrates the responses for the treatments performed. We statistically confirmed that the $\mathrm{pH}$ values decreased according to the amount of PBM added, even if they presented a satisfactory VA/TA ratio. This characterizes a possible acidification of the treatment with 5\% addition, which is different from the observation for the glycerol addition treatments where all the assays showed $\mathrm{pH}$ values between 5.77 and 5.87-very close to the $\mathrm{pH}$ value for the treatment exclusively containing ARS.
That condition, which occurred in the treatments with the addition of PBM, happened mainly because of the ready degradability of the material and its conversion into organic acids. Acidogenic bacteria are more specialized and developed, and more resistant to extreme conditions than methanogenic archaea; therefore, the production step is substantially more accelerated than the consumption of acids.

The limiting factors in this process are the rate of hydrolysis of the material to be digested and the availability of the substrate acidogenic bacteria. The rapid acidification and the increased production of acids are detrimental to the activity of the methanogenic "archaea", and allow the system to collapse.

\section{Efficiency of the removal of solids and COD}

Table 5 illustrates the efficiencies achieved for the removal of TS, VS, and COD for all the treatments assessed. 
Table 4. Output parameters of the treatments studied.

\begin{tabular}{|c|c|c|c|c|c|}
\hline \multirow{2}{*}{ Treatments } & \multicolumn{5}{|c|}{ Response } \\
\hline & $\operatorname{COD}\left(\mathrm{mg} \mathrm{L}^{-1}\right)$ & TS $\left(\mathrm{mg} \mathrm{L}^{-1}\right)$ & VS $\left(\mathrm{mg} \mathrm{L}^{-1}\right)$ & FS $\left(\mathrm{mg} \mathrm{L}^{-1}\right)$ & $\mathrm{pH}$ \\
\hline ARS (Control) & $7541.64 f$ & $7970.00 \mathrm{~d}$ & $5947.50 c$ & $2019.50 d$ & $6.07 \mathrm{a}$ \\
\hline G1 & $23268.86 \mathrm{e}$ & $10654.00 \mathrm{c}$ & $7182.50 \mathrm{c}$ & $3471.50 \mathrm{ab}$ & $5.87 \mathrm{ab}$ \\
\hline G3 & $52114.79 c$ & $10374.00 \mathrm{c}$ & $6669.02 \mathrm{c}$ & $3705.00 \mathrm{a}$ & $5.77 \mathrm{~b}$ \\
\hline G5 & $49809.52 c$ & $19883.50 \mathrm{~b}$ & $16548.53 b$ & $3335.09 \mathrm{abc}$ & $5.71 \mathrm{bc}$ \\
\hline PBM1 & $39902.10 d$ & $5323.02 \mathrm{e}$ & $3154.38 d$ & $2169.00 \mathrm{~cd}$ & $5.52 \mathrm{~cd}$ \\
\hline PBM3 & $76870.38 b$ & $5531.32 \mathrm{e}$ & $3050.50 \mathrm{~d}$ & $2480.50 \mathrm{bcd}$ & $5.39 \mathrm{~d}$ \\
\hline PBM5 & $109059.70 \mathrm{a}$ & $24563.45 \mathrm{a}$ & $20395.35^{\mathrm{a}}$ & $4167.65^{\mathrm{a}}$ & $3.64 \mathrm{e}$ \\
\hline \multicolumn{6}{|c|}{ Summary ANOVA (F value) } \\
\hline Treatments & $390.88^{*}$ & 618.44* & $276.59^{*}$ & $9.23 *$ & $253.39^{*}$ \\
\hline Block & 536.6 & 579 & 279.8 & 9.297 & 295.19 \\
\hline V.C. $(\%)$ & 7.45 & 5.51 & 10.11 & 19.95 & 2.11 \\
\hline
\end{tabular}

Averages followed by the same letter do not significantly differ among themselves according to the Tukey test, at a 5\% probability level. V.C. $(\%)=$ variation coefficient. *meaning full to the $5 \%$ probability level.

Table 5. Efficiencies of removal of TS, VTS, and COD for the treatments studied.

\begin{tabular}{lccc}
\hline \multirow{2}{*}{ Treatments } & \multicolumn{3}{c}{ Response } \\
\cline { 2 - 4 } & COD Removal (\%) & TS Removal (\%) & VS Removal (\%) \\
\hline ARS (Control) & $33.93 \mathrm{c}$ & $74.50 \mathrm{~b}$ & $73.31 \mathrm{c}$ \\
G1 & $61.65 \mathrm{ab}$ & $69.72 \mathrm{c}$ & $72.05 \mathrm{c}$ \\
G3 & $56.37^{\mathrm{a}}$ & $76.86 \mathrm{~b}$ & $80.54 \mathrm{~b}$ \\
G5 & $40.10 \mathrm{bc}$ & $63.49 \mathrm{~d}$ & $61.13 \mathrm{~d}$ \\
PBM1 & $65.91^{\mathrm{a}}$ & $84.99^{\mathrm{a}}$ & $88.17^{\mathrm{a}}$ \\
PBM3 & $63.14^{\mathrm{a}}$ & $87.89^{\mathrm{a}}$ & $91.70^{\mathrm{a}}$ \\
PBM5 & $40.74 \mathrm{bc}$ & $56.03 \mathrm{e}$ & $63.49 \mathrm{~d}$ \\
\hline Summary ANOVA (F value) & & & $59.62^{*}$ \\
Treatments & $14.26^{*}$ & $207.87^{*}$ & 58.52 \\
Block & 32.36 & 200.51 & 4.45 \\
V.C. (\%) & 15.12 & 2.40 & \\
\hline Av
\end{tabular}

Averages followed by the same letter do not significantly differ among themselves according to the Tukey test, at a $5 \%$ probability level. V.C. $(\%)=$ variation coefficient. *meaning full to the $5 \%$ probability level.

The efficiencies achieved for the removal of solids, total as well as volatile, were higher for the treatments using PBM addition in concentrations of 1 and $3 \%$, although the treatments with the addition of glycerol showed acceptable removal. It should be noted that Table 6 shows the values for the removal of solids in treatments with the addition of 1,3 , and $5 \%$ glycerol, which were above the values reported in a study by Astals et al. (2013) using biodigesters with the same residue and same glycerol load employed in the present study. 


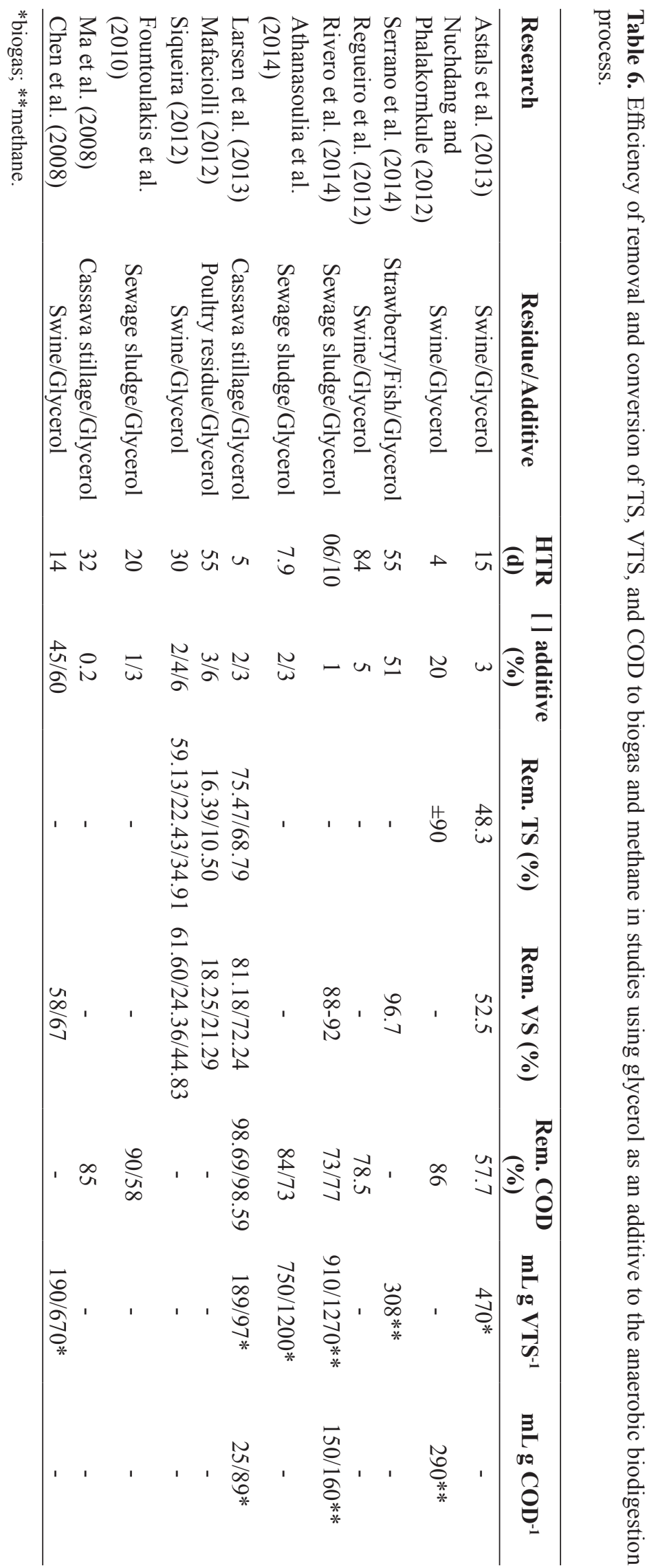


Table 5 also illustrates that the efficiency of the removal of organic material in the treatments with 1 and 3\% PBM addition is close to or above that reported in several works using agricultural residues and glycerol as an additive. It should be remembered that, in most of the experiments compared, the HRTs employed were longer than the one used in the present work. It should be noted that, for treatments with the addition of glycerol, the removal of solids increased up to the treatment with $3 \%$ addition, while a removal decrease occurred for the treatment with $5 \%$ addition of glycerol.

Although the residual glycerol represents a high organic load, which is easily degraded, it can still produce intermediaries (LYBERATOS; SKIADAS, 1999), long-chain fatty acids (HANAKI et al., 1981), and chlorides, among others. Chlorides are toxic to methanogenic microorganisms; they induce cell plasmolysis (an increase in the osmotic pressure and a consequent breakup of cells), and this effect has been studied by Riffat and Krongthamchat (2006).

The presence of sulfides in the residual glycerol is also a factor that can cause problems for biodigestion, so that concentrations of 50-125 $\mathrm{mg} \mathrm{H}_{2} \mathrm{~S} \mathrm{~L}^{-1}$ are enough to cause inhibition of the digestive process (CHEN et al., 2008). Moreover, Wohlgemut (2009), investigating the addition of glycerol to the digestion of swine residue, confirmed that the addition of $4 \%(\mathrm{w} / \mathrm{w})$ of this additive resulted in an overload of COD and a subsequent collapse of the reactor.

The removal of solids, both total and volatile, in treatments with the addition of PBM increased up to $3 \%$ addition, but there was a significant decrease when $5 \%$ of the additive was used. However, the reason for the lower rates of removal are not due to glycerol but relate to the final conditions of the reactors where the $\mathrm{pH}$ in treatments with 5\% PBM was found to be extremely low (less than 4) at the end of 6 days of digestion.
The methanogenesis stage can be up to three times slower than the acidogenesis stage. This causes an accumulation of acids in the system due to the fast hydrolysis and transformation of PBM into volatile acids, which can cause collapse of the reactors.

Regarding the removal of COD, it should be noted that the values were very close in the treatments of both residues. The treatments with the best responses for that variable were those including G1, G3, PBM1, and PBM3, which did not differ according to the test of average comparison, at 5\% probability. The results of the removal of COD were similar to those obtained by Astals et al. (2013).

\section{Production of biogas}

\section{Composition of the biogas}

Biogas usually comprises a mixture of gases, the major constituents being methane and carbon dioxide. Their levels are determined by the characteristics of the residue, conditions of operation, and biodigestion process (COLDEBELLA et al., 2008). Coldebella et al. (2008) reported that the average content of methane in the biogas was approximately $65 \%$, the remaining gases being carbon dioxide with traces of nitrogen, hydrogen, hydrogen sulfide, and carbon monoxide. Methane is responsible for the high levels of thermal energy generated by biogas because it has high thermal capacity $\left(9.9 \mathrm{~kW} \mathrm{~h} \mathrm{~m}^{-3}\right)$. Likewise, biogas with methane levels between 50 and $80 \%$ presents thermal capacity between 4.95 and $7.9 \mathrm{~kW} \mathrm{~h} \mathrm{~m}^{-3}$ (CCE, 2000).

Figure 2 shows the average composition of methane and carbon dioxide in all the treatments. It should be noted that the methane level was high in all the treatments, especially in G1, G3, and PBM3. 
Figure 2. Average composition of biogas in the treatments analyzed.

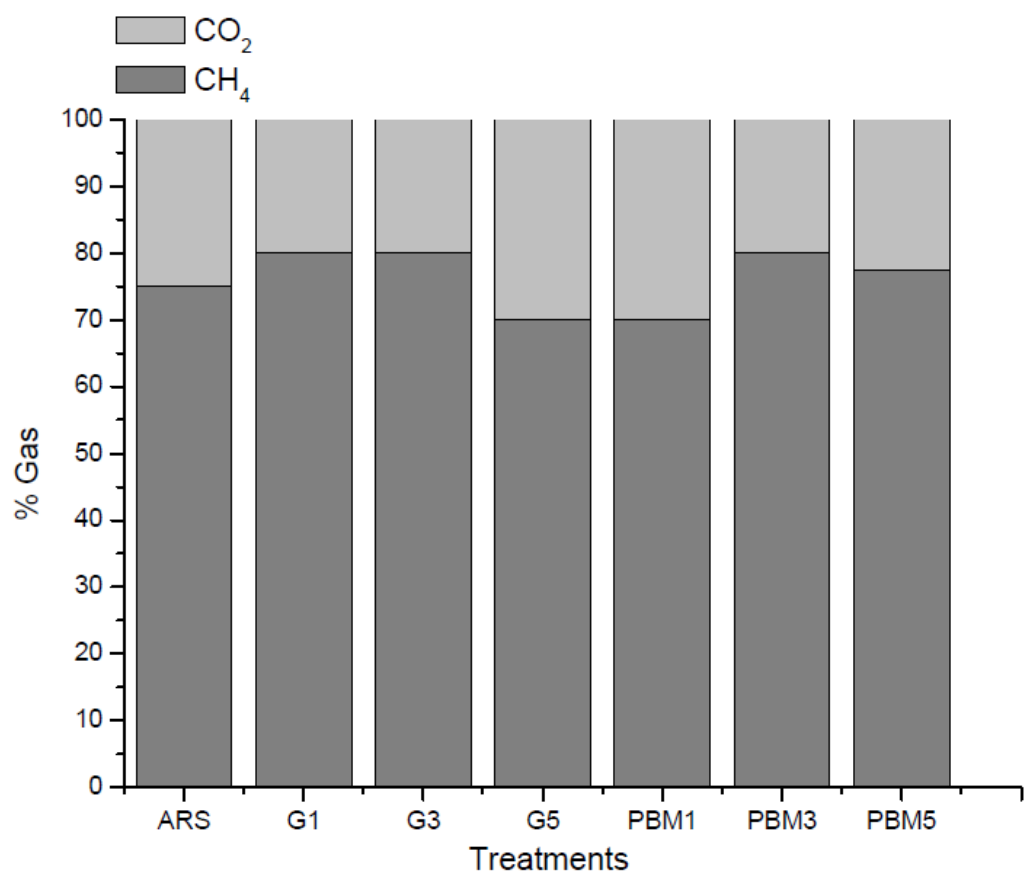

The high content of methane in all treatments arises from the composition of the degraded material and the additive, being composed mainly of proteins, lipids, and carbohydrates. These components can produce average methane levels ranging from 50 to 74\% (XIE et al., 2012).

Rivero et al. (2014) reported the production of biogas with methane levels ranging from 49.93 to $62.39 \%$ in a study on sewage sludge biodigestion involving the addition of glycerol. Guo et al. (2013) reported biodigestion processes involving biodegradable foams, based on wheat, potato, and corn starches (95\% starch content), in which methane levels of $65 \%$ were obtained, in relation to the total biogas percentage generated. Moreover, in research performed by Kryvoruchko et al. (2009) involving the digestion of potato byproducts rich in starch, biogas methane levels of approximately $50-54 \%$ were obtained. The values reported by both teams were below those achieved in the present research. The high methane content endows the biogas with higher thermal power, giving it superior combustion properties and higher efficiency as a fuel.

\section{Production of biogas and methane}

Figure 3 shows a comparison of the production profile of biogas for the treatments assessed; it can be seen that the addition of both glycerol and PBM resulted in high biogas production after the first day of fermentation. The rapid and ready degradation of PBM accounts for the greater production of biogas on the first day of biodigestion, but there was a decrease from the third day of operation onwards. In the case of treatments using glycerol, a higher daily production was obtained by treatment G1, while in the case of treatments using PBM as an additive, a higher daily production was obtained in treatment PBM3. In both 5\% treatments, the production of biogas was similar to or lower than the control treatment. 
Figure 3. Comparison of the production profile of biogas in treatments with addition of glycerol and PBM.

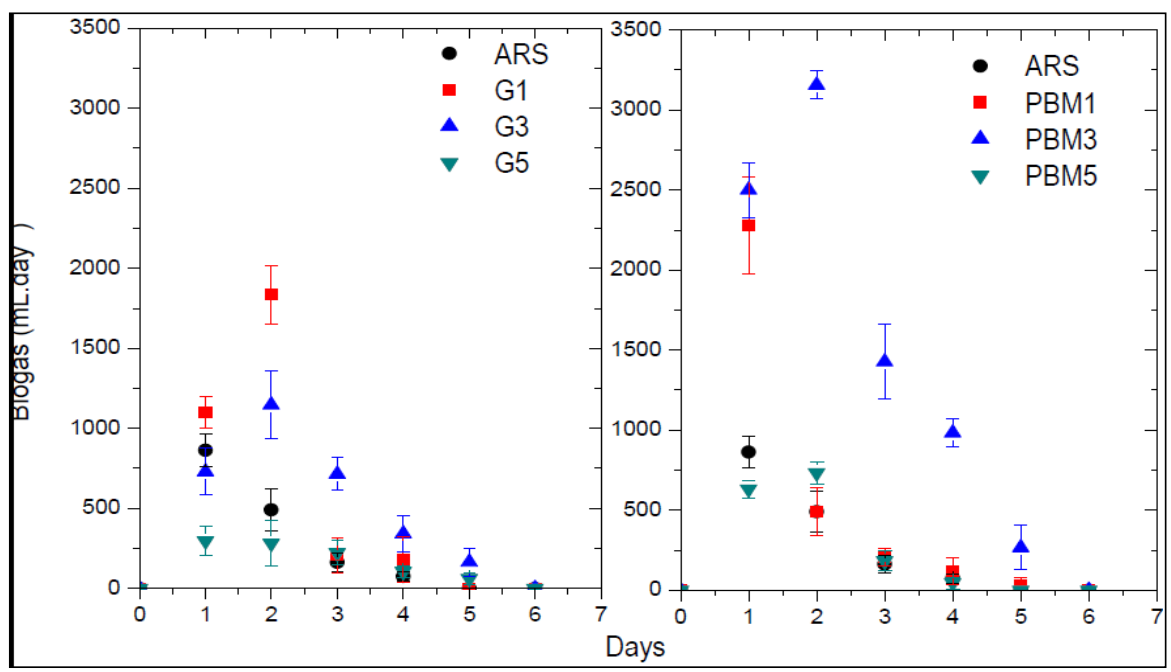

The treatment with PBM5 showed reduced values of output $\mathrm{pH}$ and low rates of organic material removal, possibly due to the high rate of degradation of PBM into volatile acids, causing an abrupt fall of $\mathrm{pH}$ and a subsequent decrease in the activity of the methanogenic "archaea". In the case of treatment G5, in contrast to treatment PBM5, it is possible that the high content of additive resulted in an overload of the COD or even a high input of impurities, which can be harmful to the biodigestion process.

Table 7 shows the values of the total production of biogas and methane in the treatments studied.
The additions of glycerol at 1 and $3 \%$ and PBM1 resulted in an increase of greater than $100 \%$ in the production of biogas and methane; however, they did not differ statistically among themselves. The greater cumulative productions occurred in treatment PBM3, with a biogas production of $523 \%$ higher than production in the control treatment, and the methane production was $558 \%$ higher than in the control. The production levels of biogas and methane resulting from this treatment were much higher than that with the best treatment involving the addition of glycerol.

Table 7. Cumulative production of biogas and methane in the treatments studied.

\begin{tabular}{lcc}
\hline \multirow{2}{*}{ Treatments } & \multicolumn{2}{c}{ Response } \\
\cline { 2 - 3 } ARS (Control) & Biogas $(\mathbf{m L})$ & Methane $(\mathbf{m L})$ \\
\cline { 2 - 3 } G1 & $1593.09 \mathrm{c}$ & $1194.82 \mathrm{c}$ \\
G3 & $3524.15 \mathrm{~b}$ & $2819.32 \mathrm{~b}$ \\
G5 & $3097.87 \mathrm{~b}$ & $2478.30 \mathrm{~b}$ \\
PBM1 & $972.62 \mathrm{c}$ & $680.83 \mathrm{c}$ \\
PBM3 & $3126.41 \mathrm{~b}$ & $2188.48 \mathrm{~b}$ \\
PBM5 & $8336.28 \mathrm{a}$ & $6669.02 \mathrm{a}$ \\
\hline Summary ANOVA (F value) & $1596.05 \mathrm{c}$ & $1236.94 \mathrm{c}$ \\
\hline Treatments & & \\
Block & $155.60^{*}$ & $166.85^{*}$ \\
V.C. (\%) & 159.42 & 169.71 \\
\hline
\end{tabular}

Averages followed by the same letter do not significantly differ among themselves according to the Tukey test, at a 5\% probability level. V.C. $(\%)=$ variation coefficient. *meaning full to the $5 \%$ probability level. 
The fitting of the Gompertz model to the experimental data for the different concentrations of glycerol and PBM investigated in the present study is illustrated in Figures $4 \mathrm{a}$ and $4 \mathrm{~b}$, respectively. Biogas production decreased in all treatments until termination on the third day of fermentation, with the exception of the PBM3 treatment, which maintained high production until the fourth day, showing that this was the possible period of consumption of the material employed as an additive.

Figure 4a. Cumulative production of biogas in the treatments studied with addition of glycerol, where: $\mathrm{A}=\mathrm{Control}$; $\mathrm{B}=\mathrm{G} 1 ; \mathrm{C}=\mathrm{G} 3$; D = G5 (up). Figure 4b. Cumulative production of biogas in the treatments studied with addition of PBM, where: $\mathrm{A}=$ Control; $\mathrm{B}=\mathrm{PBM} 1 ; \mathrm{C}=\mathrm{PBM} 3$; $\mathrm{D}=\mathrm{PBM}$ (down).
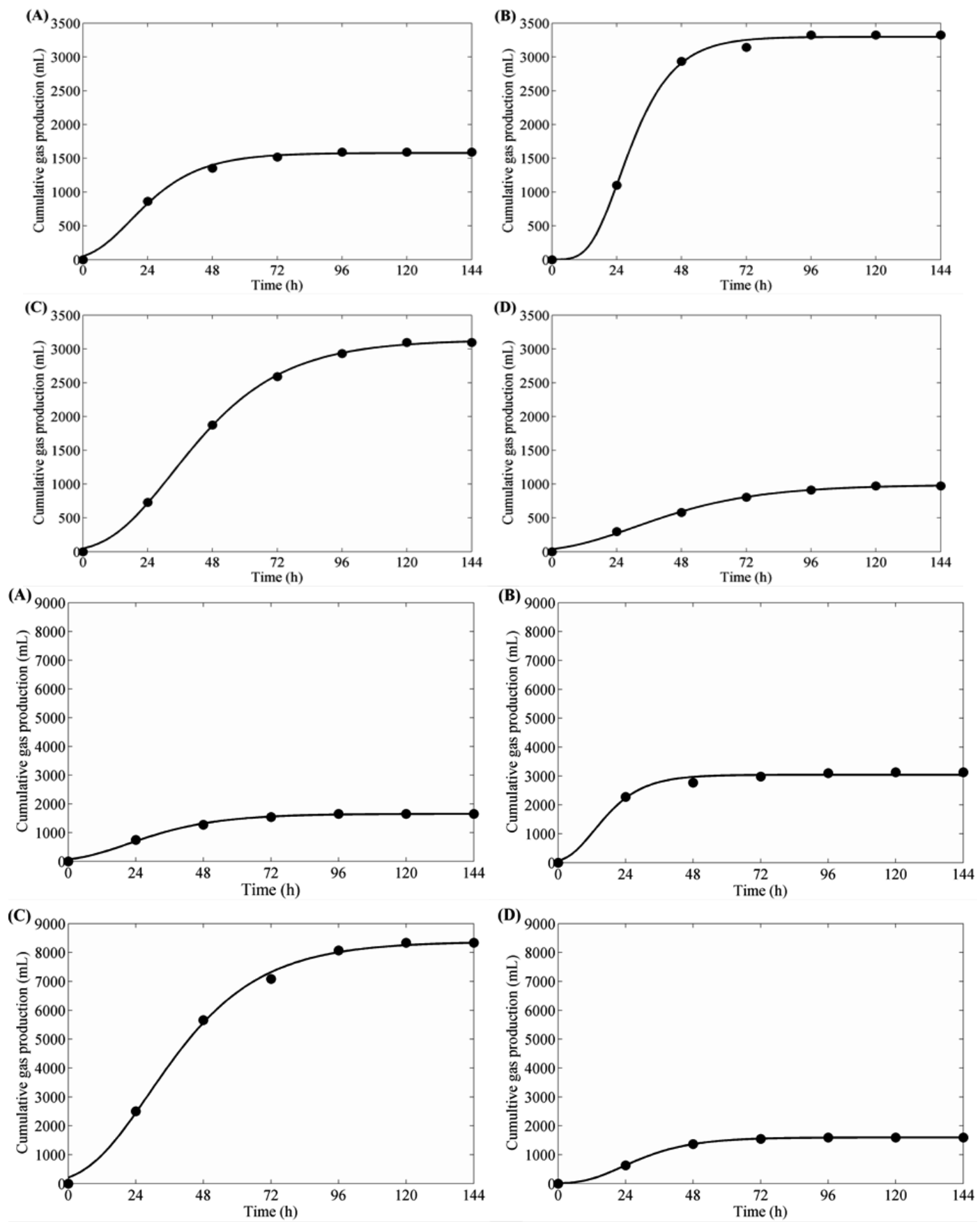
Table 8 shows the estimated values for the parameters of the model, with a $95 \%$ confidence interval and determination coefficient for the four treatments investigated in the present study. In general, all the data sets were described by the model, obtaining $\mathrm{R}^{2}$ values higher than 0.99 in all cases.

Table 8. Optimized parameters for the Gompertz model from the data for the experimental treatments.

\begin{tabular}{lllll}
\hline \multirow{2}{*}{ Treatments } & $P(m L)$ & $R(m L / h)$ & $\lambda(h)$ & $R^{2}$ \\
\hline \multirow{2}{*}{ ARS } & 1579 & 40.58 & 3.34 & 0.9966 \\
& $(1516,1642)$ & $(28.59,52.57)$ & $(-3.294,9.974)$ & \\
G1 & 3298 & 109.4 & 13.9 & 0.9987 \\
& $(3208,3388)$ & $(83.96,134.9)$ & $(10.76,17.04)$ & \\
G3 & 3136 & 50.19 & 9.907 & 0.9995 \\
& $(3065,3206)$ & $(45.87,54.51)$ & $(7.207,12.61)$ & \\
G5 & 990 & 14.09 & 4.788 & 0.9971 \\
& $(931.6,1048)$ & $(11.23,16.94)$ & $(-2.285,11.86)$ & \\
ARS & 1654 & 33.63 & 3.203 & 0.9963 \\
& $(1575,1733)$ & $(24.77,42.49)$ & $(-3.726,10.13)$ & \\
PBM1 & 3042 & 118.1 & 3.386 & 0.9914 \\
\multirow{2}{*}{ PBM3 } & $(2874,3210)$ & $(48.56,187.7)$ & $(-8.208,14.98)$ & \\
& 8379 & 141.6 & 6.739 & 0.9982 \\
PBM5 & $(8038,8721)$ & $(117,166.2)$ & $(1.504,11.97)$ & \\
& $(1597$ & 43.47 & 9.491 & 0.9990 \\
\hline
\end{tabular}

The parameters summarized in Table 8 reveal that for the treatments using glycerol as an additive, a greater specific rate of biogas production was obtained for treatment $\mathrm{G} 1\left(109.4 \mathrm{~mL} \mathrm{~h}^{-1}\right)$, and for treatments using PBM, a greater specific rate was obtained for treatment PBM3 (141.6 $\left.\mathrm{mL} \mathrm{h}^{-1}\right), 29.4 \%$ better than the best treatment with glycerol. These treatments also refer to those that achieved the highest cumulative production of biogas. A future study on an industrial level, where the production rate is the basic parameter of the process, should test the most efficient treatments for total gas production. Only the treatments using 5\% glycerol as an additive presented a biogas production rate lower than the control treatment, the specific order of production being: $\mathrm{PBM} 3>\mathrm{PBM} 1>\mathrm{G} 1>\mathrm{G} 3>$ PBM5 > ARS $>$ G5.

In both treatments with $5 \%$ additive, the rates of production were lower than with the other concentrations, confirming the results discussed previously concerning the toxic effects of high concentrations of glycerol, as well as the acidification of the medium at higher concentrations of PBM, on methanogenic bacteria.

The relationships between the production of biogas and methane are shown in Table 9; the best rates for the conversion of volatile solids to biogas and methane were observed for treatments G1 and PBM3. These treatments also produced the highest cumulative amounts of biogas and methane. In the other treatments, the trend was the same, where the order of conversion was related to the order of values of biogas and methane production in the treatments.

The variations in the conversion of VS can be explained by the characteristics of these materials. VS can be subdivided into biodegradable VS and refractory VS. The refractory VS comprises a group of complex materials such as lignin that are difficult to degrade. 
Table 9. Relationship between VS and COD conversion to biogas and methane in the treatments studied.

\begin{tabular}{|c|c|c|c|c|}
\hline \multirow{2}{*}{ Treatments } & \multicolumn{4}{|c|}{ Response } \\
\hline & mL biogas $\mathrm{g} \mathrm{VS}^{-1}$ & $\mathrm{~mL} \mathrm{CH}_{4} \mathrm{~g} \mathrm{VS}^{-1}$ & $\mathrm{~mL}$ biogas g COD $^{-1}$ & $\mathrm{~mL} \mathrm{CH}_{4} \mathrm{~g} \mathrm{COD}^{-1}$ \\
\hline ARS (Control) & $97.54 d$ & $73.16 \mathrm{~cd}$ & $245.11 \mathrm{a}$ & $171.58 \mathrm{a}$ \\
\hline G1 & $179.56 b$ & $143.65 b$ & $143.01 b$ & $114.41 b$ \\
\hline G3 & $112.23 \mathrm{~cd}$ & $89.78 \mathrm{c}$ & $59.57 \mathrm{~cd}$ & $47.66 \mathrm{~cd}$ \\
\hline G5 & $37.37 \mathrm{e}$ & $26.16 \mathrm{e}$ & $19.51 \mathrm{~d}$ & $13.66 \mathrm{~d}$ \\
\hline PBM1 & $133.04 \mathrm{c}$ & $93.13 \mathrm{c}$ & $79.31 \mathrm{bc}$ & $55.52 \mathrm{~cd}$ \\
\hline PBM3 & $247.49 a$ & $197.99 a$ & $108.78 \mathrm{bc}$ & $87.03 \mathrm{bc}$ \\
\hline PBM5 & $60.41 \mathrm{e}$ & $46.82 \mathrm{de}$ & $14.68 \mathrm{~d}$ & $11.38 \mathrm{~d}$ \\
\hline \multicolumn{5}{|c|}{ Summary ANOVA (F value) } \\
\hline Treatments & $85.90 *$ & $94.17 *$ & $23.14^{*}$ & $23.85^{*}$ \\
\hline Block & 2.35 & 2.01 & 2.75 & 2.58 \\
\hline V.C. $(\%)$ & 13.95 & 14.07 & 38.99 & 36.81 \\
\hline
\end{tabular}

Averages followed by the same letter do not significantly differ among themselves according to the Tukey test, at a 5\% probability level. V.C. $(\%)=$ variation coefficient. *meaning full to the $5 \%$ probability level.

When the production of biogas and methane was analyzed in terms of the removal of COD, the values were reversed and the control treatment was the one that showed the highest rates of conversion.

The VS and COD conversion values for biogas and methane in the anaerobic treatments employing additives were highly variable according to the literature. Table 6 reveals that it is possible to evaluate the average conversion rates of the organic matter during biodigestion with the use of additives in order to increase the production of biogas.

The values of VS conversion to biogas in the treatments employing glycerol were extremely low compared with the values reported in the literature, whereas the values of biogas production using $3 \%$ PBM treatment were similar to those reported by Larsen et al. (2013) in the digestion of cassava wastewater, and by Chen et al. (2008) performing ARS digestion. Further, the values obtained with the addition of glycerol were much lower than those found in other studies such as that conducted by Astals et al. (2013), wherein the obtained values were much higher than those in the present study using ARS with the addition of 3\% glycerol.

\section{Conclusions}

We can conclude that the use of PBM yielded better results regarding the production of biogas and methane compared with the addition of glycerol. The highest production levels were obtained with the 3\% PBM and $1 \%$ glycerol treatments. Additive concentrations of $5 \%$ PBM harmed the biodigestion process owing to the high production of volatile acids and the subsequent acidification of the reactors; further, additions of 3\% glycerol or higher decreased the digestion rate. Most treatments presented high rates of removal for total solids and volatile solids. Only the 5\% PBM and 5\% glycerol treatments achieved reductions lower than $70 \%$.

\section{References}

ALFAKIT. Kit Análise de biogás com biofoto microprocessado. [S.1.: s.n], 2016. Available at: $<$ http:// www.alfakit.ind.br/kit-analise-de-biogas-com-biofotomicroprocessado-cod-2297/1/>. Access at: 15 feb. 2016.

ALVES, G. S.; SAMPAIO, A. P. L.; ZAVOLSKI, C. A.; BRITO, V. H.; CEREDA, M. P.; NEVES, E. Material a base de amido de mandioca para manufatura de embalagem de alimentos. Revista Citino, Barra do Burgues, v. 2, n. 1, p. 16-24, 2012.

AMERICAN PUBLIC HEALTH ASSOCIATION APHA. Standard methods. $19^{\text {th }}$ ed. Washington, DC.: American Public Health Association, 1995. 
AQUINO, S. F.; CHERNICHARO, C. A. L.; FORESTI, E.; SANTOS, M. de L. F. dos; MONTEGGIA, L. O. Metodologias para determinação da atividade metanogênica específica (AME) em lodos anaeróbios. Engenharia Sanitaria e Ambiental, Rio de Janeiro, v. 12, n. 2, p. 192-201, 2007.

ASTALS, S.; NOLLA-ARDÈVOLB, V.; MATAALVAREZA, J. Thermophilic co-digestion of pig manure and crude glycerol: process performance and digestate stability. Journal of Biotechnology, Bielefeld, v. 166, n. 3, p. 97-104, 2013.

ATHANASOULIA, E.; MELIDIS, P.; AIVASIDIS, A. Co-digestion of sewage sludge and crude glycerol from biodiesel production. Renewable Energy, v. 62, n. 1, p. 73-78, 2014.

BHATNAGAR, A.; SAIN, M. Processing of cellulose nanofiber-reinforced composites. Journal of Reinforced Plastics Composites, Stanford, v. 24, n. 12, p. 1259-1268, 2005.

BRIDGWATER, A. V.; MEIER, D.; RADLEIN, D. An overview of pyrolysis of biomass. Organic Geochemistry, v. 30, n. 12 , p. 1479-1493, 1999.

CARMO, F. R.; EVANGELISTA, N. S.; SANTIAGOAGUIAR, R. S.; FERNANDES, F. A. N.; SANT'ANA, H. B. Evaluation of optimal activity coefficient models for modeling and simulation of liquid-liquid equilibrium of biodiesel + glycerol + alcohol systems. Fuel, v. 125, n. 1, p. 57-65, 2014.

CAVINATO, C.; FATONE, F.; BOLZONELLA, D.; PAVAN, P. Thermophilic anaerobic co-digestion of cattle manure with agro-wastes and energy crops: comparison of pilot and full scale experiences. Bioresource Technology, v. 101, n. 2, p. 545-550, 2010.

CENTRO PARA CONSERVAÇÃO E ENERGIA - CCE. Guia técnico de biogás. Amadora: [s.n.], 2000. 117 p.

CHEN, Y.; CHENG, J. J.; CREAMER, K. S. Inhibition of anaerobic digestion process: a review. Bioresource Technology, v. 99, n. 10, p. 4044-4064, 2008.

CHERNICHARO, C. A. L. Anaerobic reactors: principles of biological treatment of wastewater. Belo Horizonte: Politécnica, 1997. 379 p.

COLDEBELLA, A.; SOUZA, S. N. M.; FERRI, P.; KOLLING, E. M. Viabilidade da geração de energia elétrica através de um motor gerador utilizando biogás da suinocultura. Informe Gepec, Toledo, v. 12, n. 2, p. 45-55, 2008.

CORRADINI, E.; AGNELLI, J. A. M.; MORAIS, L. C. de; MATTOSO, L. H. C. Study of properties of biodegradable composites of $\mathrm{starch} /$ gluten/glycerol reinforced with sisal fibers. Polimeros: Ciência $e$ Tecnologia, São Carlos, v. 18, n. 4, p. 353-358, 2008.

FERNANDES JÚNIOR, A. Digestão anaeróbia de manipueira com separação de fases: cinética da fase acidogênica. 1995. Tese (Doutorado em Energia na Agricultura) - Faculdade de Ciências Agronômicas. Universidade Estadual Paulista, Botucatu.

FOUNTOULAKIS, M. S.; PETOUSI, I.; MANIOS, T. Co-digestion of sewage sludge with glycerol to boost biogas production. Waste Management, v. 30, n. 10, p. 1849-1853, 2010.

FREITAS, C.; PENTEADO, M. Biodiesel energia do futuro. São Paulo: Letra Boreal, 2006. 146 p.

GUO, M.; STUCKEY, D. C.; MURPHY, R. J. End-oflife of starch-polyvinyl alcohol biopolymers. Bioresource Technology, v. 127, n. 1, p. 256-266, 2013.

HANAKI, K.; MATSUO, T.; NAGASE, M. Mechanism of inhibition caused by long- chain fatty acids in anaerobic digestion process. Biotechnology and Bioengineering, v. 23, n. 7, p. 1591-1610, 1981.

KRYVORUCHKO, V.; MACHMULLER, A.; BODIROZA, V.; AMON, B.; AMON, T. Anaerobic digestion of by-products of sugar beet and starch potato processing. Biomass \& Bioenergy, v. 33, n. 4, p. 620-627, 2009.

LARSEN,A. C. Co-digestão anaeróbia de glicerina bruta e efluente de fecularia. 2009. Dissertação (Mestrado em Engenharia Agrícola) - Universidade Estadual do Oeste do Paraná, Cascavel.

LARSEN, A. C.; BENEDITTO, M. G.; GOMES, S. D.; ZENATTI, D. C.; TORRES, D. G. B. Anaerobic codigestion of crude glycerin and starch industry effluent. Engenharia Agrícola, Jaboticabal, v. 33, n. 2, p. 341-352, 2013.

LAY, J. J.; LI, Y. Y.; NOIKE, T. Effect of moisture content and chemical nature on methane fermentation characteristics of municipal solid wastes. Journal of Environmental System and Engineering, v. 7, n. 552, p. 101-108, 1996.

Influences of $\mathrm{pH}$ and moisture content on the methane production in high-solids sludge digestion. Water Research, v. 31, n. 6, p. 1518-1524, 1997.

LYBERATOS, G.; SKIADAS, I. V. Modelling of anaerobic digestion: a review. Global Nest: the Intitutional Journal, Patras, v. 1, n. 2, p. 63-76, 1999.

MA, J.; VAN WAMBEKE, M.; CARBALLA, M.; VERSTRAETE, W. Improvement of the anaerobic treatment of potato processing wastewater in a UASB 
reactor by co-digestion with glycerol. Biotechnology Letters, Netherlands, v. 30, n. 5, p. 861-867, 2008.

MAFACIOLli, D. Produção de Biogás através do processo de digestão anaeróbia utilizando dejetos de aves de postura com suplementação de glicerina bruta. 2012. Monografia (Trabalho de Conclusão de Curso de Graduação em Engenharia Ambiental) - Centro Universitário UNIVATES, Lajeado.

MIURA, A. K.; FORMAGGIO,A. R.; SHIMABUKURO, Y. E.; ANJOS, S. D. dos; LUIZ, A. J. B. Avaliação de áreas potenciais ao cultivo de biomassa para produção de energia e uma contribuição de sensoriamento remoto e sistemas de informações geográficas. Engenharia Agrícola, Jaboticabal, v. 31, n. 3, p. 607-620, 2011.

NUCHDANG, S.; PHALAKORNKULE, C. Anaerobic digestion of glycerol and co-digestion of glycerol and pig manure. Journal of Environmental Management, Heverlee, v. 101, n. 1, p. 164-172, 2012.

OREGON STATE DEPARTMENT OF ENERGY ODOE. Biomass energy technology. Salem: Oregon, 2002. Available at: <http://www.oregondoe.org/>. Accessed at: 23 jun. 2014.

OSAKI, M.; BATALHA, M. O. Produção de biodiesel e óleo vegetal no Brasil: realidade e desafios. Organizações Rurais \& Agroindustriais, Lavras, v. 13, n. 2, p. 227-242, 2011.

PARAMESWARAN, P.; RITTMANN, B. E. Feasibility of anaerobic co-digestion of pig waste and paper sludge. Bioresource Technology, v. 124, n. 1, p. 163-168, 2012.

REGUEIRO, L.; CARBALlA, M.; ÁlVAREZ, J. A.; LEMA, J. M. Enhanced methane production from pig manure anaerobic digestion using fish and biodiesel wastes as co-substrates. Bioresource Technology, v. 123, n. 1, p. 507-513, 2012.

RIFFAT, R.; KRONGTHAMCHAT, K. Specific methanogenic activity of halophilic and mixed cultures in saline wastewater. International Journal of Environmental Science and Technology, New York, v. 2, n. 4, p. 291-299, 2006.

RIPLEY, L. E.; BOYLE, W. C.; CONVERSE, J. C. Improved alkalimetric monitoring for anaerobic digestion of high-strength wastes. Journal Water Pollution Control Federation, v. 58, n. 5, p. 406-411, 1986.

RIVERO, M.; SOLERA, R.; PEREZ, M. Anaerobic mesophilic co-digestion of sewage sludge with glycerol: Enhanced biohydrogen production. International Journal of Hidrogen Energy, v. 39, n. 6, p. 2481-2488, 2014.

SANTIBAÑEZ, C.; VARNERO, M. T.; BUSTAMANTE, M. Residual glycerol from biodiesel manufacturing, waste or potential source of bioenergy: a review. Chilean journal of agricultural research, Chillán, v. 71, n. 3, p. 469-475, 2011.

SERRANO, A.; SILES, J. A.; CHICA, A. F.; MARTIN, M. A. Improvement of mesophilic anaerobic co-digestion of agri-food waste by addition of glycerol. Journal of Environmental Management, v. 140, n. 1, p. 76-82, 2014.

SILVA, M. O. S. A. Análises físico-químicas para controle das estações de tratamento de esgotos. São Paulo: Companhia de Tecnologia de Saneamento Ambiental - CETESB, 1977. 226 p.

SIQUEIRA, J. Co-digestão de glicerina bruta associada a esterco bovino na produção de biogás. 2012. Dissertação (Mestrado em Bioenergia) - Universidade Estadual do Oeste do Paraná, Toledo.

VAN HAANDEL, A. C. Influence of the digested cod concentration on the alkalinity requirement in anaerobic digesters. Water Science and Technology, London, v. 30, n. 8, p. 23-34, 1994.

WOHLGEMUT, O. Co-digestion of hog manure with glycerol to boost biogas and methane production. 2009. Dissertation (Master Civil Engineering) - Faculty of Graduate Studies, University of Manitoba, Winnipeg.

XAVIER, C. A. N.; LUCAS JÚNIOR, J. Parâmetros de dimensionamento para biodigestores batelada operados com dejetos de vacas leiteiras com e sem uso de inoculo. Engenharia Agrícola, Jaboticabal, v. 30, n. 2, p. 212-223, 2010.

XIE, S.; WU, G.; LAWLOR, P. G.; FROST, J. P.; ZHAN, $X$. Methane production from anaerobic co-digestion of the separated solid fraction of pig manure with dried grass silage. Bioresource Techonology, v. 104, n. 1, p. 289-297, 2012.

YADVIKA, S.; SREEKRISHNAN, T. R.; KOHLI, S.; RANA, V. Enhancement of biogas production from solid substrates using different techniques - a review. Bioresource Technology, v. 95, n. 1, p. 1-10, 2004.

YE, J.; LI, D.; DOM, Y.; WANG, G.; YUAN, Z.; ZHEN, F.; WANG, Y. Improved biogas production from rice straw by co-digestion with kitchen waste and pig manure. Waste Management, v. 33, n. 12, p. 2653-2658, 2013.

YUSUF, M. O. L.; DEBORA, A.; OGHENERUONA, D. E. Ambient temperature kinetic assessment of biogas production from co-digestion of horse and cow dung. Research in Agricultural Engineering, v. 57, n. 3, p. 97 104, 2011.

ZHANG, X. Q.; DO, M. D.; DEAN, K.; HOOBIN, P.; BURGAR, I. M. Wheat-gluten-based natural polymer nanoparticle composites. Biomacromolecules, v. 8 , n. 2, p. 345-353, 2007. 
